ISSN 1678-3921

Journal homepage: www.embrapa.br/pab

For manuscript submission and journal contents, access: www.scielo.br/pab

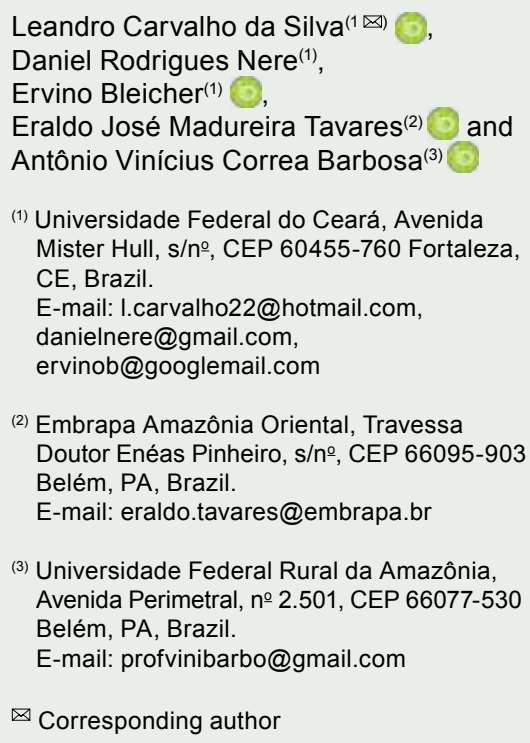

\section{Preferences and demographic parameters of cowpea aphid on advanced lines of semiprostrate cowpea}

\begin{abstract}
The objective of this work was to determine the preference and the demographic parameters of cowpea aphid (Aphis craccivora) in advanced lines of semiprostrate cowpea (Vigna unguiculata), and to verify both the existance and type of plant resistance to this insect attack. Aphid preference to 20 cowpea genotypes was tested in a randomized complete block design, with six replicates. Lines showing the highest levels of resistance and susceptibility in the preference tests were selected for use in the demographic parameter tests. Based on aphid birth rate and mortality, fertility life tables were constructed. The MNCO4-792F-123 line was classified as resistant. The lowest values for cowpea aphid intrinsic and finite growth rates were obtained for the MNCO4-792F-123, and the highest ones for MNCO4-782F-108 and 'BRS Novaera' genotypes, whose levels exceeded those of 'Vita 7', the standard genotype for susceptibility. The MNCO4-792F-123 line is the least favorable for the development of cowpea aphid, while MNCO4-782F-108 and 'BRS Novaera' are the most susceptible ones.
\end{abstract}

Index terms: Aphis craccivora, Vigna unguiculata, plant resistance.

\section{Preferência e parâmetros demográficos do pulgão-preto em linhagens avançadas de feijão-caupi de porte semiprostrado}

Resumo-O objetivo deste trabalho foi determinar a preferência e os parâmetros demográficos do pulgão-preto (Aphis craccivora), em linhagens avançadas de feijão-caupi (Vigna unguiculata) de porte semiprostrado, e verificar a existência e o tipo de resistência da planta ao ataque do inseto. Avaliou-se a preferência do inseto a 20 genótipos de feijão-caupi, em delineamento de blocos ao acaso, com seis repetições. As linhagens com maior resistência e suscetibilidade nos testes de preferência foram selecionadas para compor o ensaio de parâmetros demográficos. Com base na taxa de natalidade e mortalidade do pulgão, construíram-se as tabelas de vida de fertilidade. A linhagem MNCO4-792F-123 foi classificada como resistente. Os menores valores da taxa intrínseca de crescimento e da taxa finita de crescimento do pulgão-preto ocorreram sobre a linhagem MNCO4-792F-123, e os maiores, sobre os genótipos MNCO4-782F-108 e 'BRS Novaera', que superaram o genótipo-padrão de suscetibilidade 'Vita 7'. A linhagem MNCO4-792F-123 é a menos favorável para o desenvolvimento do pulgão-preto, enquanto MNCO4-782F-108 e 'BRS Novaera' são as mais suscetíveis.

Termos para indexação: Aphis craccivora, Vigna unguiculata, resistência de plantas. 


\section{Introduction}

Cowpea [Vigna unguiculata (L.) Walp.] is a widely cultivated legume in the semiarid tropics of Africa and the United States (Huynh et al., 2015). In Brazil, the species is mainly cultivated in the North and Northeast by small-holder family farmers because of the low cost of production. In these regions a high proportion of the rural population depends on cowpea for their nutritional and economic subsistence, as this crop is highly nutritious because it is rich in carbohydrates and proteins, and because it is a source of employment and income (Silva \& Neves, 2011; Freitas et al., 2014). However, phytosanitary problems can substantially reduce cowpea productivity.

Among the phytosanitary problems that can negatively influence cowpea productivity are attacks by Aphis craccivora Koch (Hemiptera: Aphididae), also known as cowpea aphid. This pest species causes great damage to the crop, as it can cause both direct effects (from sap sucking), and indirect ones, as the insect is a vector for several viruses that cause diseases for which there is no treatment (Moraes \& Bleicher, 2007; Valente et al., 2014; Huynh et al., 2015).

Due to the difficulty small producers have to acquire insecticides to control this pest, the use of cultivars with superior characteristics and resistance to cowpea aphid would be an effective, safe, and economical alternative (Moraes \& Bleicher, 2007; Silva \& Bleicher, 2010).

In Brazil, in recent years, research has been carried out to test the resistance of $V$. unguiculata to cowpea aphid, and to identify potential sources of resistance to it (Silva \& Bleicher, 2010; Silva et al., 2012; Bandeira et al., 2015; Melville et al., 2016). There are reports on the susceptibility of several cowpea cultivars (released to the market) to cowpea aphid (Melville et al., 2016; Silva et al., 2018a). A study on the resistance to cowpea aphid in fifteen semi-erect cowpea lines, developed for the medium and large farmer, the authors observed that only two genotypes were resistant to the insect (Silva et al., 2018b). If one of these lines was to be launched without a full knowledge of its aphid-resistance capacity, purchasing farmers could end up making costly applications of insecticides, with a consequent reduction of profit and increase of local agrotoxicity.

The knowledge on semiprostrate cowpea lineages susceptibility to aphid is essential, since these lines may soon be the new cultivars launched to the market, and most are destined to small farmers.
The objective of this work was to determine the preference and the demographic parameters of cowpea aphid in advanced lines of semiprostrate cowpea, and to verify both the existance and type of plant resistance to this insect attack.

\section{Materials and Methods}

The experiments were carried out in the first semester of 2016, at the Centro de Ciências Agrárias ( $3^{\circ} 40^{\prime} 24^{\prime \prime} \mathrm{S}$ and $38^{\circ} 34^{\prime} 32^{\prime \prime} \mathrm{W}$, at $12 \mathrm{~m}$ altitude), Pici Campus, Universidade Federal do Ceará, in the municipality of Fortaleza, in the state of Ceará, Brazil.

The work was conducted under a $200 \mu$ plastic covering net as roof, and by an anti-aphid screening in the sides.

Using genotypes and lines provided by Embrapa Meio-Norte (Table 1), in the municipality of Teresina, in the state of Piauí, Brazil, a cowpea aphid genotype preference trial was carried out on plants from 16 advanced semiprostrate lines, besides two standardresistance and two standard-susceptibility genotypes to Aphis craccivora to allow of comparison between lineages (treatments).

Three-hole, $300 \mathrm{~mL}$ polyethylene pots were used, each one filled with a compost of subsoil, humus, and vermiculite at 6:3:1 proportions. The experiment was carried out in a randomized block design with six replicates, and each plant of a given treatment was considered a plot.

Before plant infestation, aphid colonies to be used were age-standardized. For this, plants of 'Vita 7' a very susceptible cultivar to cowpea aphid - were infested with adult aphids, on the twelfth day after planting. After 24 hours, all adults were removed, and only nymphs produced in this period. When these nymphs reached the adulthood, they were used in the experimental plant infestation.

Genotypes were experimentally infested on the twelfth day after planting, and five six-day-old adult, apterous females were placed on each plant. After infestation, plants were grouped into experimental blocks, and the pots for each treatment were placed on benches without touching them, and protected with a cage covered by $1.0 \times 1.0 \times 0.5 \mathrm{~m}$ anti-aphid screening.

The evaluation was carried out in two stages. The first one was performed 48 hours after infestation, when the live adults were counted, and then removed 
from the plants. The second stage was performed 96 hours after infestation, when the number of live nymphs was counted.

To evaluate resistance of the various lines, the number of adults and live nymphs were transformed by the formula $(x+0.5)^{0.5}$. An analysis of variance was performed, and the means were separated by a ScottKnott test, at 5\% probability.

Following the analysis of variance results, means were ranked following the method proposed by Mulamba \& Mock (1978), and the lowest mean was considered to have the greatest interest to the research. With the sum of the occupied ranks corresponding to the number of adults and live nymphs, it was possible to calculate the effective resistance (ER), which represents the joint action of the genotype on adult insects and nymphs. In a free-choice plant infestation trials with adult insects, according to Silva \& Bleicher (2010),

Table 1. Semiprostrate genotypes/lines of cowpea (Vigna unguiculata) with their respective parents, or provenance, evaluated for resistance to cowpea aphid (Aphis craccivora) and type of resistance.

\begin{tabular}{|c|c|}
\hline Genotype/line & Parent/origin \\
\hline MNCO4-768F-16 & (TE97-321G-2 x CE-315) \\
\hline MNCO4-768F-21 & (TE97-321G-2 x CE-315) \\
\hline MNCO4-768F-25 & (TE97-321G-2 x CE-315) \\
\hline MNCO4-769F-26 & (CE-315 x TE97-304G-12) \\
\hline MNCO4-769F-27 & (CE-315 x TE97-304G-12) \\
\hline MNCO4-769F-31 & (CE-315 x TE97-304G-12) \\
\hline MNCO4-769F-45 & (CE-315 x TE97-304G-12) \\
\hline MNCO4-769F-46 & (CE-315 x TE97-304G-12) \\
\hline MNCO4-769F-49 & (CE-315 x TE97-304G-12) \\
\hline MNCO4-769F-55 & (CE-315 x TE97-304G-12) \\
\hline MNCO4-774F-78 & (TE97-309G-18 x TE97-304G-4) \\
\hline MNCO4-774F-90 & (TE97-309G-18 x TE97-304G-4) \\
\hline MNCO4-782F-108 & $\begin{array}{c}((\text { TE97-309G-24 x TE96-406-2E-28-2) x } \\
\text { TE97-309G-24) }\end{array}$ \\
\hline MNCO4-792F-123 & (MNCOO-533D-8-1-2-3 x TVx5058-09C) \\
\hline MNCO4-792F-129 & (MNCOO-533D-8-1-2-3 x TVx5058-09C) \\
\hline MNCO4-795F-158 & (MNC99-518G-12 x IT92KD-279-3) \\
\hline Vita $7^{(1)}$ & IITA \\
\hline $\mathrm{TVu} 408 \mathrm{P}_{2}^{(2)}$ & IITA \\
\hline BR 17-Gurguéia ${ }^{(1)}$ & (BR 10-Piauí x CE-315 (TVu 2331) \\
\hline $\begin{array}{l}\text { BRS Guariba (TE96- } \\
282-22 \mathrm{G})^{(2)}\end{array}$ & (IT85-2687 x TE87-98-8G) \\
\hline
\end{tabular}

the insects may be attracted to other plants, or may migrate from them. The attraction indicates the insect preference, and the migration from a plant indicates a nonpreference-type resistance (antixenosis). Another form of reaction is the insect death when infesting a plant, which characterizes the antibiosis.

Results of effective resistance were also ranked and, together with the ranking of the number of adults and nymphs, a new multivariate analysis was performed, which gave rise to the mean number of ranks (Xr), a result that represents the reaction of the genotype to aphid infestation. Means were separated by the ScottKnott test, at 5\% probability. Xr-based data were tested for the normality and homogeneity of residue variances.

Demographic parameters were estimated using results of the screening of insect food preferences. The lineages MNCO4-769F-46, MNCO4-782F-108, MNCO4-792F-123, and MNCO4-792F-129 were used, as they showed either the greatest susceptibility, or resistance, to A. craccivora (estimated by preference or avoidance by the insect, respectively), together with the aphid-susceptible genotypes 'Vita 7', and 'BRS Novaera' (a recently-launched semi-erect cowpea cultivar).

Pot type, and form of planting, thinning, and age standardization of test plants were all identical to those used in the preliminary preference tests. Tests for plant infestation occurred on the twelfth day after sowing, when five adult aphids were deposited on each plant in the early hours of the day. Infested plants were placed on benches without touching, and covered with cages coated with $1.0 \times 1.0 \times 0.50 \mathrm{~m}$ anti-aphid screens. The research design consisted of six treatments with ten replicates.

Four hours after infestation, adult insects were removed, and two nymphs were left per plant for a 24-hour period. To construct fertility life tables, cohorts of 10 individual insects were constructed, based on one nymph per plant, which were monitored daily. Counts were made for the number of live individuals, the number of offsprings (which were removed after counting), and the longevity of the insects in the cohort.

Biological data were collected to construct $A$. craccivora fertility life tables. Based on the information obtained from these tables (such as daily number of offsprings and survivorship in each age group), the following parameters were determined: survivorship, calculated based on the first observed descendant (S 
$1^{\text {st }} \mathrm{D}$ - a metric that indicates the chances of nymphs reaching adulthood and procreating; gross reproduction rate (GRR), which is the total mean number of nymphs produced per female over its reproductive life (Hoque et al., 2008); and the relationship between $R_{0} / G R R$, for which values closer to 1.0 indicate the plant genotype with a higher level of suitability as food for aphid. Cowpea aphid demographic parameters were estimated with the jackknife method (Maia et al., 2000) by SAS statistical program (SAS Institute Inc., Cary, NC, USA), as follows: net reproduction rate $\left(\mathrm{R}_{\mathrm{O}}\right)$; mean between-generation intervals $(\mathrm{T})$; population doubling time $\left(\mathrm{T}_{\mathrm{D}}\right)$; intrinsic rate of increase $\left(\mathrm{r}_{\mathrm{m}}\right)$; and finite rate of increase $(\lambda)$.

Subsequently, the means were ranked following Mulamba \& Mock (1978), in an order that gave a favorable ranking to resistance, so that those lines with the lowest score (more-resistant) were considered the most relevant ones to the research. With the sum of rankings corresponding to the evaluated parameters, the rank sum $(\Sigma r)$ was calculated, which represents the joint action of the genotype on aphid population parameters.

\section{Results and Discussion}

Preference studies showed that the number of surviving adult aphids and live nymphs was influenced by cowpea genotype. For the number of adults, the lines fell into two groups, while for the number of nymphs, there were three groups (Table 2). MNCO4-792F-123 did not differ from 'BRS Guariba' and $\mathrm{TVu} 408 \mathrm{P}_{2}$ standard genotypes, for the number of adult aphids. It also showed no significant difference from $\mathrm{TVu} 408 \mathrm{P}_{2}$ for the number of nymphs, and showed the lowest number of nymphs for any of the 16 evaluated lineages.

Adult aphids showed no preference for 'BRS Guariba', MNCO4-792F-123, and TVu $408 \quad \mathrm{P}_{2}$ genotypes as sites of reproduction, and the numbers of offsprings produced were also lower on these materials (Table 2). These facts indicate antibiosis, mainly due to the low-offspring production levels.

As to the average number of ranks (Xr), two groups were formed; in one of them, out of the 16 cowpea lines, four were aphid-resistant, and in the other group, 12 lines were susceptible (Table 2). There was no difference between the advanced lines MNCO4-
792F-123, MNCO4-792F-129, MNCO4-774F-78, and MNCO4-769F-27, and the standard genotypes 'BRS Guariba' and TVu $408 \mathrm{P}_{2}$, indicating that they were all resistant to cowpea aphid.

The genotypes MNCO4-795F-158, MNCO4768F-21, MNCO4-769F-26, MNCO4-769F-49, MNCO4-769F-31, MNCO4-769F-45, MNCO4769F-55, MNCO4-768F-16, MNCO4-774F-90, MNCO4-768F-25, 'BR 17-Gurguéia', MNCO4-769F-46, MNCO4-782F-108 and 'Vita 7' were all classified as susceptible to cowpea aphid (Table 2). From these, 'BR 17-Gurguéia' and 'Vita 7' had already been reported as susceptible to cowpea aphid (Moraes \& Bleicher, 2007; Silva \& Bleicher, 2010; Silva et al., 2018b). Therefore, the number of advanced lines showing susceptibility to cowpea aphid is high, that is, out of the 16 tested genotypes there was a total of 12 lines.

One of the possible reasons why 12 of the 16 evaluated lines were susceptible to aphids involves the nature of their parent genotypes, CE-315 and TE97304G-12. These are relevant because 'BR 17-Gurguéia', described as susceptible to cowpea aphid, has as its female parent the genotype CE-315 (Silva \& Neves, 2011). Thus, when cross-breeding used genotypes CE-315 and TE97-304G-12 as parents, susceptible offsprings were generated, as with 'BR 17-Gurguéia', which had CE-315 as a parent. According to Babura \& Mustapha (2012), when crossing $V$. unguiculata using resistant and susceptible genotypes to $A$. craccivora in the $\mathrm{F}_{1}$, offsprings that are highly resistant to aphids will be obtained in the $\mathrm{F}_{2}$ and subsequent backcrosses. This is because, in A. craccivora, resistance to cowpea aphid is linked to a dominant gene. In the current study, lines with CE-315 and TE97-304G-12 as parents were classified as susceptible to cowpea aphid. Since the gene for A. craccivora-resistance is dominant, it is believed that none of these lines have it. Therefore, lines derived from crosses between parents derived from these genotypes will lack the genetic combination that favors the resistance to cowpea aphid, a fact that could explain the large number of susceptible lines.

The cowpea line MNCO4-792F-123 reduced by half the first descendant survival rate (S 1st D) of aphids (Table 3). The probability of aphids surviving the nymphal phase is low, therefore, this effect in this line reduces the aphid chances of establishing a breeding adult population. MNCO4-792F-123 had also the lowest GRR (30.94). This decrease of aphid reproductive 
capacity may be related to differences in the nutritional quality between host plants, which can impact the insect reproductive capacity (La Rossa et al., 2013).

The net reproductive $\left(\mathrm{R}_{\mathrm{O}}\right)$ values of aphids differed between the evaluated genotypes. Those fed on MNCO4-792F-123, MNCO4-769F-46, and MNCO4$792 \mathrm{~F}-129$ had lower- $\mathrm{R}_{\mathrm{O}}$ values $(9.3,20.7$ and 23.7) than those feeding on 'BRS Novaera' (Table 3). Low $\mathrm{R}_{\mathrm{O}}$ is indicative that MNCO4-792F-123, MNCO4-769F-46, and MNCO4-792F-129 have all caused a reduction of female capacity to increase the population in each generation, that is typical of antibiosis deploying as a defense mechanism by a resistant line.

For $\mathrm{R}_{\mathrm{O}} / \mathrm{GRR}$ values, MNCO4-792F-123 (0.30) appeared to be the most unpalatable to aphids (Table 3). This was probably due to the presence of secondary compounds such as nitrogen (alkaloids) and terpenoids (limonoids and curcubitacins), both of which reduce overall palatability in bean plants (Aoyama \& Labinas, 2012).

Values for the mean interval - from 6.55 to $7.75-$ between generations $(\mathrm{T})$ did not differ between the evaluated genotypes, (Table 3). As to population doubling time $\left(\mathrm{T}_{\mathrm{D}}\right)$, two different groups were formed. Insects raised on MNCO4-782F-108 plants had the lowest $\mathrm{T}_{\mathrm{D}}$ (1.16 days), while the period was longer (1.91 days) for those raised on MNCO4-792F-123, indicating the impacts of plant resistance on the aphid population dynamics.

The intrinsic rate of increase $\left(\mathrm{r}_{\mathrm{m}}\right)$ of cowpea aphid ranged from 0.35 to 0.59 (Table 3). Aphids raised on MNCO4-782F-108 and 'BRS Novaera' had $r_{m}$ values of 0.59 and 0.56 , respectively, which were higher than the $r_{m}$ on other genotypes, indicating that these hosts were most favorable for aphid population increase. In contrast, MNCO4-792F-123, MNCO4-792F-129, and MNCO4-769F-46 ( $r_{m}$ of $0.35,0.40$, and 0.44 ) were the

Table 2. Genotypes, average number of adults (NA), number of nymphs (NN), effective resistance (ER), and rank average (Xr) for cowpea aphid (Aphis craccivora) on genotypes of semiprostrate cowpea (Vigna unguiculata) ${ }^{(1)}$.

\begin{tabular}{|c|c|c|c|c|c|c|c|}
\hline Genotype & $\mathrm{NA}^{(2)}$ & $\operatorname{Rank}^{(4)}$ & $\mathrm{NN}^{(3)}$ & Rank $^{(4)}$ & ER & $\operatorname{Rank}^{(4)}$ & $\mathrm{Xr}^{(5)}$ \\
\hline BRS Guariba & $0.00 \mathrm{a}$ & 1 & $2.17 \mathrm{a}$ & 1 & 2 & 1 & $1.00 \mathrm{a}$ \\
\hline $\mathrm{TVu} 408 \mathrm{P}_{2}$ & $1.33 \mathrm{a}$ & 3 & $44.17 b$ & 2 & 5 & 2 & $2.33 \mathrm{a}$ \\
\hline MNCO4-792F-123 & $1.17 \mathrm{a}$ & 2 & $46.00 \mathrm{~b}$ & 3 & 5 & 2 & $2.33 \mathrm{a}$ \\
\hline MNCO4-792F-129 & $3.17 \mathrm{~b}$ & 5 & $72.17 \mathrm{c}$ & 5 & 10 & 3 & $4.33 \mathrm{a}$ \\
\hline MNCO4-774F-78 & $3.67 b$ & 7 & $63.83 \mathrm{c}$ & 4 & 11 & 4 & $6.00 \mathrm{a}$ \\
\hline MNCO4-769F-27 & $3.67 \mathrm{~b}$ & 7 & $74.73 c$ & 6 & 13 & 5 & $6.00 \mathrm{a}$ \\
\hline MNCO4-795F-158 & $3.67 \mathrm{~b}$ & 7 & $80.67 \mathrm{c}$ & 10 & 17 & 6 & $7.66 \mathrm{~b}$ \\
\hline MNCO4-769F-21 & $4.17 \mathrm{~b}$ & 10 & $77.50 \mathrm{c}$ & 8 & 18 & 7 & $8.33 b$ \\
\hline MNCO4-769F-26 & $4.00 \mathrm{~b}$ & 9 & $79.50 \mathrm{c}$ & 9 & 18 & 7 & $8.33 b$ \\
\hline MNCO4-769F-49 & $3.50 \mathrm{~b}$ & 6 & $83.33 c$ & 12 & 18 & 7 & $8.33 b$ \\
\hline MNCO4-769F-31 & $4.50 \mathrm{~b}$ & 12 & $75.50 \mathrm{c}$ & 7 & 19 & 8 & $9.00 \mathrm{~b}$ \\
\hline MNCO4-769F-45 & $3.67 \mathrm{~b}$ & 7 & $85.00 \mathrm{c}$ & 13 & 20 & 9 & $9.66 \mathrm{~b}$ \\
\hline MNCO4-769F-55 & $2.83 \mathrm{~b}$ & 4 & $88.33 \mathrm{c}$ & 17 & 21 & 10 & $10.33 b$ \\
\hline MNCO4-768F-16 & $4.33 b$ & 11 & $83.17 \mathrm{c}$ & 11 & 22 & 11 & $11.00 \mathrm{~b}$ \\
\hline MNCO4-774F-90 & $3.83 \mathrm{~b}$ & 8 & $85.67 \mathrm{c}$ & 14 & 22 & 11 & $11.00 \mathrm{~b}$ \\
\hline MNCO4-768F-25 & $3.67 \mathrm{~b}$ & 7 & $87.00 \mathrm{c}$ & 16 & 23 & 12 & $11.66 \mathrm{~b}$ \\
\hline BR 17-Gurguéia & $4.00 \mathrm{~b}$ & 9 & $86.83 c$ & 15 & 24 & 13 & $12.33 b$ \\
\hline MNCO4-769F-46 & $3.67 \mathrm{~b}$ & 7 & $108.33 \mathrm{c}$ & 20 & 27 & 14 & $13.66 \mathrm{~b}$ \\
\hline MNCO4-782F-108 & $4.50 \mathrm{~b}$ & 12 & $93.00 \mathrm{c}$ & 18 & 30 & 15 & $15.00 \mathrm{~b}$ \\
\hline Vita 7 & $4.33 \mathrm{~b}$ & 11 & $105.83 \mathrm{c}$ & 19 & 30 & 15 & $15.00 \mathrm{~b}$ \\
\hline Snedecor's F-test & $4.86^{* *}$ & - & $5.10^{* *}$ & - & - & - & $5.28 * *$ \\
\hline Coefficient of variation (\%) & 23.86 & - & 25.44 & - & - & - & 35.47 \\
\hline
\end{tabular}


least favorable genotypes for aphids. Various studies report that some cowpea genotypes negatively impacted A. craccivora demographic parameters, including a decrease of intrinsic growth rate (Obopile \& Ositile, 2010; Machacha et al., 2012; Aliyu \& Ishiayaku, 2013). However, $r_{m}$ values found by these authors were lower than those obtained in the present study, which can be attributed to environmental conditions and differences between the studied cowpea genotypes.

In the present study, MNCO4-792F-123, MNCO4792F-129, and MNCO4-769F-46 showed the lowest finite rate of increase $(\lambda)$ estimates $(1.42,1.50$, and 1.56 , respectively), and differed for this parameter from the other evaluated genotypes (Table 3). According to the finite growth rate values obtained, planting the newlyreleased cowpea cultivar, 'BRS Novaera', and the MNCO4-782F-108 lineages, may induce outbreaks of this pest if other conditions are favorable.

MNCO4-792F-123 had the smallest sum of rank ( $\Sigma$ r) value (Table 3 ). Thus, among the evaluated lines, MNCO4-792F-123 is the least susceptible line to the pest, using an antibiosis resistance mechanism that reduces female fecundity and increases mortality in the nymph phase (Silva et al., 2018a, 2018b).

Resistance tests classified MNCO4-769F-46 as susceptible (Table 2). However, when demographic parameters were estimated, this same line showed some resistance, as indicated by the $\mathrm{R}_{\mathrm{O}}, \mathrm{r}_{\mathrm{m}}$, and $\lambda$ values, which were lower than those from reference genotypes considered as susceptible ones (Table 3).

One of the reasons for this variation of resistance may be related to the aphid life stage because adults were used for the preference test, while nymphs were used for demographic tests. Possibly, during feeding, adults were adversely affected either by a secondary compound, or by the nutritional quality of the plant, while in situ during the resistance test. However, this fact did not directly impact the immediate reproductive output, as aphid embryos within females complete about $2 / 3$ of their development before they are born, and because aphid reproduction involves viviparous parthenogenesis, as soon as they are born females already have a young developing inside them, and within these there are granddaughters (Dixon, 1998; Ogawa \& Miura, 2014). As a consequence, the plant might not have been able to substantially affect the fecundity of the founding adult aphids but, when the feeding began in the following nymph phase, these insects had their reproductive capacity altered resulting in high subsequent mortality. This is likely to occur because an aphid cohort exposed to harmful substances from the first instar will show higher

Table 3. Demographic parameters for survivorship observed on the first descendant ( $\left.S 1^{\text {st }} \mathrm{D}\right)$, gross reproduction rate (GRR), net reproduction rate $\left(R_{0}\right), R_{0} / G R R$ ratio, mean between generation intervals $(T)$, population doubling time $\left(T_{D}\right)$, intrinsic rate of increase $\left(\mathrm{r}_{\mathrm{m}}\right)$, finite rate of increase $(\lambda)$, and rank sum $\left(\sum \mathrm{r}\right)$ for cowpea aphid (Aphis craccivora) on genotypes of semiprostrate cowpea (Vigna unguiculata) $)^{(1)}$.

\begin{tabular}{|c|c|c|c|c|c|c|c|c|c|c|c|c|c|c|c|c|c|}
\hline \multirow[b]{2}{*}{ Genotype } & \multicolumn{17}{|c|}{ Demographic parameters } \\
\hline & $\begin{array}{c}\mathrm{S} 1^{\text {st }} \\
\mathrm{D}(\%)\end{array}$ & $\mathrm{R}$ & GRR & $\mathrm{R}$ & $\mathrm{R}_{\mathrm{O}}$ & $\mathrm{R}$ & $\begin{array}{c}\mathrm{R}_{\mathrm{O}} / \\
\mathrm{GRR}\end{array}$ & $\mathrm{R}$ & $\mathrm{T}$ & $\mathrm{R}$ & $\mathrm{T}_{\mathrm{D}}$ & $\mathrm{R}$ & $\mathrm{r}_{\mathrm{m}}$ & $\mathrm{R}$ & $\lambda$ & $\mathrm{R}$ & $\sum r^{(2)}$ \\
\hline Vita 7 & 90 & 4 & 56.64 & 4 & $\begin{array}{c}43.6 \mathrm{a} \\
(32.2-54.9)\end{array}$ & 4 & 0.77 & 5 & $\begin{array}{c}6.82 \mathrm{a} \\
(6.33-7.31)\end{array}$ & 3 & $\begin{array}{c}1.25 \mathrm{~b} \\
(1.19-1.30)\end{array}$ & 4 & $\begin{array}{c}0.55 \mathrm{a} \\
(0.53-0.57)\end{array}$ & 4 & $\begin{array}{c}1.74 \mathrm{a} \\
(1.70-1.78)\end{array}$ & 4 & 32.00 \\
\hline $\begin{array}{l}\text { MNCO- } \\
4-769 \mathrm{~F}-46\end{array}$ & 60 & 2 & 49.66 & 3 & $\begin{array}{c}20.7 b c \\
(12.0-29.4)\end{array}$ & 2 & 0.42 & 2 & $\begin{array}{c}6.78 \mathrm{a} \\
(5.76-7.81)\end{array}$ & 4 & $\begin{array}{c}1.54 \mathrm{a} \\
(1.39-1.69)\end{array}$ & 3 & $\begin{array}{c}0.44 \mathrm{~b} \\
(0.40-0.49)\end{array}$ & 3 & $\begin{array}{c}1.56 \mathrm{~b} \\
(1.49-1.64)\end{array}$ & 3 & 22.00 \\
\hline $\begin{array}{l}\text { MNCO- } \\
4-782 \mathrm{~F}-108\end{array}$ & 90 & 4 & 68.28 & 5 & $\begin{array}{c}49.0 \mathrm{a} \\
(36.2-61.8)\end{array}$ & 5 & 0.72 & 6 & $\begin{array}{c}6.55 \mathrm{a} \\
(6.05-7.07)\end{array}$ & 5 & $\begin{array}{c}1.16 \mathrm{~b} \\
(1.06-1.27)\end{array}$ & 6 & $\begin{array}{c}0.59 \mathrm{a} \\
(0.54-0.64)\end{array}$ & 6 & $\begin{array}{c}1.81 \mathrm{a} \\
(1.72-1.90)\end{array}$ & 6 & 43.00 \\
\hline $\begin{array}{l}\text { MNCO- } \\
4-792 \mathrm{~F}-123\end{array}$ & 50 & 1 & 30.94 & 1 & $\begin{array}{c}9.3 \mathrm{c} \\
(2.9-15.7)\end{array}$ & 1 & 0.30 & 1 & $\begin{array}{c}6.30 \mathrm{a} \\
(4.29-7.68)\end{array}$ & 6 & $\begin{array}{c}1.91 \mathrm{a} \\
(1.35-2.48)\end{array}$ & 1 & $\begin{array}{c}0.35 \mathrm{~b} \\
(0.25-0.45)\end{array}$ & 1 & $\begin{array}{c}1.42 \mathrm{~b} \\
(1.28-1.57)\end{array}$ & 1 & 13.00 \\
\hline $\begin{array}{l}\text { MNCO- } \\
4-792 F-129\end{array}$ & 80 & 3 & 45.13 & 2 & $\begin{array}{c}23.7 \mathrm{~b} \\
(16.6-30.8)\end{array}$ & 3 & 0.52 & 3 & $\begin{array}{c}7.75 a \\
(6.48-9.03)\end{array}$ & 1 & $\begin{array}{c}1.69 \mathrm{a} \\
(1.35-2.03)\end{array}$ & 2 & $\begin{array}{c}0.40 \mathrm{~b} \\
(0.32-0.48)\end{array}$ & 2 & $\begin{array}{c}1.50 \mathrm{~b} \\
(1.38-1.62)\end{array}$ & 2 & 18.00 \\
\hline $\begin{array}{l}\text { BRS } \\
\text { Novaera }\end{array}$ & 100 & 5 & 75.73 & 6 & $\begin{array}{c}55.7 \mathrm{a} \\
(42.9-68.4)\end{array}$ & 6 & 0.73 & 4 & $\begin{array}{c}7.17 \mathrm{a} \\
(6.82-7.53)\end{array}$ & 2 & $\begin{array}{c}1.23 \mathrm{~b} \\
(1.18-1.29)\end{array}$ & 5 & $\begin{array}{c}0.56 \mathrm{a} \\
(0.53-0.58)\end{array}$ & 5 & $\begin{array}{c}1.75 \mathrm{a} \\
(1.71-1.79)\end{array}$ & 5 & 38.00 \\
\hline
\end{tabular}

(1)Means followed by equal letters in the columns, do not differ by the t-test, at $5 \%$ probability. R, rank occupied when the variable was observed. (2)The lower the sum of ranks, the more likely are the genotypes to be resistant, considering the eight evaluated parameters. Number between parentheses are the minimum and maximum observed values. 
mortality (either directly or via reduced fecundity) than those partly exposed through the cycle (Hallad et al., 2011; Bortolotto et al., 2015). Overall, this will lower the reproductive capacity of the cohort.

The advanced line MNCO4-792F-123 may help reduce the incidence of aphid infestation on the crop, since this line decreases the reproductive capacity of the pest. Therefore, the cultivation of semiprostrate cowpea MNCO4-792F-123 should reduce the use of chemical insecticides in the control of the insect, which would help protect the natural enemies of the aphid. In addition, there would be a reduction of agricultural worker poisoning and environmental pollution. Finally, this would also reduce the financial expenses, and increase the cowpea productivity, with a consequent increase of the profitability for small-scale cowpea farmers.

\section{Conclusions}

1. The advanced MNCO4-792F-123 line of semiprostrate cowpea is naturally resistant to the cowpea aphid, which favors its use as a new cultivar.

2. In the evaluated cowpea lines, the resistance to cowpea aphid attack occurred in the form of antibiosis.

\section{Acknowledgments}

To Conselho Nacional de Desenvolvimento Cientifico e Tecnológico (CNPq) and to Embrapa Meio Norte, for financial support.

\section{References}

ALIYU, H.; ISHIYAKU, M.F. Identification of novel resistance gene sources to cowpea aphid (Aphis craccivora Koch) in cowpea (Vigna unguiculata L.). Pakistan Journal of Biological Sciences, v.16, p.743-746, 2013. DOI: https://doi.org/10.3923/ pjbs.2013.743.746.

AOYAMA, E.M.; LABINAS, A.M. Características estruturais das plantas contra a herbivoria por insetos. Enciclopédia Biosfera, v.8, p.365-386, 2012. Available at: <http://www.conhecer.org. br/enciclop/2012b/ciencias $\% 20$ agrarias/caracteristicas $\% 20$ estruturais.pdf $>$. Accessed on: Apr. 292019.

BABURA, S.R.; MUSTAPHA, Y. Screening for development of host plant resistance to infestation by aphid (Aphis craccivora Koch) in cowpea (Vigna unguiculata [L] Walp). Bajopas, v.5, p.44-47, 2012. DOI: https://doi.org/10.4314/bajopas.v5i1.9.

BANDEIRA, H.F. da S.; LIMA, A.C.S.; STRUCKER, A.; TRASSATO, L.B.; DIONISIO, L.F.S. Preferência do pulgão-preto e da cigarrinha-verde em diferentes genótipos de feijão-caupi em
Roraima. Revista Agro@mbiente On-line, v.9, p.79-85, 2015. DOI: https://doi.org/10.5327/Z1982-8470201500011998.

BORTOLOTTO, O.C.; BUENO, A. de F.; QUEIROZ, A.P. de; SILVA, G.V. Larval development of Spodoptera eridania and Spodoptera frugiperda fed on fresh ear of field corn expressing the $B t$ proteins (CrylF and Cry1F + Cry1A.105 + Cry2Ab2). Ciência Rural, v.46, p.1898-1901, 2016. DOI: https://doi.org/10.1590/0103$8478 \mathrm{cr} 20151461$.

DIXON, A.F.G. Aphid ecology an optimization approach. $2^{\text {nd }}$ ed. London: Chapman \& Hall, 1998. 300p.

FREITAS, R.M.O. de; DOMBROSKI, J.L.D.; FREITAS, F.C.L. de; NOGUEIRA, N.W.; PINTO, J.R. de S. Crescimento de feijãocaupi sob efeito de veranico nos sistemas de plantio direto e convencional. Bioscience Journal, v.30, p.393-401, 2014. Available at: $\quad<$ http://www.seer.ufu.br/index.php/biosciencejournal/article/ view/17982/13754>. Accessed on: Apr. 292019.

HALLAD, A.; UDIKERI, S.S.; PATIL, S.B.; KHADI, B.M.; BIRADAR, D.P.; BASAVANA GOUD, K.; BHAT, A.R.S. Characterization of resistance of different cry toxins to early and late instar Helicoverpa armigera (Hub.) and Spodoptera litura (Fab.). Karnataka Journal of Agricultural Science, v.24, p.300302, 2011.

HOQUE, M.F.; ISLAM, W.; KHALEQUZZAMAN, M. Life tables of two-spotted spider mite Tetranychus urticae Koch (Acari: Tetranychidae) and its predator Phytoseiulus persimilis Athias-Henriot (Acari: Phytoseiidae). Journal of Bio-Science, v.16, p.1-10, 2008. DOI: https://doi.org/10.3329/jbs.v16i0.3733.

HUYNH, B.-L.; EHLERS, J.D.; NDEVE, A.; WANAMAKER, S.; LUCAS, M.R.; CLOSE, T.J.; ROBERTS, P.A. Genetic mapping and legume synteny of aphid resistance in African cowpea (Vigna unguiculata L. Walp) grown in California. Molecular Breeding, v.35, art.36, 2015. DOI: https://doi.org/10.1007/s11032-015-0254-0.

LA ROSSA, F.R.; VASICEK, A.; LÓPEZ, M.C. Effects of pepper (Capsicum annuum) cultivars on the biology and life table parameters of Myzus persicae (Sulz.) (Hemiptera: Aphididae). Neotropical Entomology, v.42, p.634-641, 2013. DOI: https://doi.org/10.1007/s13744-013-0166-9.

MACHACHA, M.; OBOPILE, M.; TSHEGOFATSO, A.B.N.; TIROESELE, B.; GWAFILA, C.; RAMOKAPANE, M. Demographic parameters of cowpea aphid Aphis craccivora (Homoptera: Aphididae) on different Botswana cowpea landraces. International Journal of Tropical Insect Science, v.32, p.189193, 2012. DOI: https://doi.org/10.1017/S1742758412000318.

MAIA, A. de H.N.; LUIZ, A.J.B.; CAMPANHOLA, C. Statistical inference on associated fertility life table parameters using jackknife technique: computational aspects. Journal of Economic Entomology, v.93, p.511-518, 2000. DOI: https://doi. org/10.1603/0022-0493-93.2.511.

MELVILLE, C.C.; LIMA, A.C.S.; MORAIS, E.G.F. de; OLIVEIRA, N.T. de. Preferência do pulgão-preto, Aphis craccivora Koch (Hemiptera: Aphididae), a genótipos de feijãocaupi. Revista Agro@mbiente On-line, v.10, p.153-160, 2016. DOI: https://doi.org/10.18227/1982-8470ragro.v10i2.3042.

MORAES, J.G.L.; BLEICHER. E. Preferência do pulgão-preto, Aphis craccivora Koch, a diferentes genótipos de feijão-de-corda, 
Vigna unguiculata (L.) Walp. Ciência Rural, v.37, p.1554-1557, 2007. DOI: https://doi.org/10.1590/S0103-84782007000600008.

MULAMBA, N.N.; MOCK, J.J. Improvement of yield potential of the Eto Blanco maize (Zea mays L.) population by breeding for plant traits. Egyptian Journal of Genetics and Cytology, v.7, p.40-51, 1978.

OBOPILE, M.; OSITILE, B. Life table and population parameters of cowpea aphid, Aphis craccivora Koch (Homoptera: Aphididae) on five cowpea Vigna unguiculata (L.) Walp. varieties. Journal of Pest Science, v.83, p.9-14, 2010. DOI: https://doi.org/10.1007/ s10340-009-0262-0.

OGAWA, K.; MIURA, T. Aphid polyphenisms: trans-generational development regulation through viviparity. Frontiers in Physiology, v.5, art.1, 2014. DOI: https://doi.org/10.3389/ fphys.2014.00001.

SILVA, J.A.L. da; NEVES, J.A. Produção de feijão-caupi semiprostrado em cultivos de sequeiro e irrigado. Revista Brasileira de Ciências Agrárias, v.6, p.29-36, 2011. https://doi.org/10.5039/ agraria.v6ila748.

SILVA, J.F. da; BERTINI, C.H.C. de M.; BLEICHER, E.; MORAES, J.G.L. Divergência genética de genótipos de feijãode-corda quanto à resistência ao pulgão-preto. Pesquisa
Agropecuária Brasileira, v.47, p.948-954, 2012. DOI: https://doi.org/10.1590/S0100-204X2012000700011.

SILVA, J.F. da; BLEICHER, E. Resistência de genótipos de feijãode-corda ao pulgão-preto. Pesquisa Agropecuária Brasileira, v.45, p.1089-1094, 2010. DOI: https://doi.org/10.1590/S0100$204 X 2010001000006$.

SILVA, L.C. da; NERE, D.R.; BLEICHER, E.; BARBOSA, A.V.C.; TAVARES, E.J.M. Demographic parameters of aphid in cowpea cultivars. Ciência Agrícola, v.16, p.69-76, 2018a. DOI: https://doi.org/10.28998/rca.v16i1.3782.

SILVA, L.C. da; NERE, D.R.; BLEICHER, E.; BARBOSA, A.V.C.; TAVARES, E.J.M. Demographic parameters of cowpea aphids on advanced semi-erect cowpea lines. Pesquisa Agropecuária Brasileira, v.53, p.900-908, 2018b. DOI: https://doi.org/10.1590/ S0100-204X2018000800004.

VALENTE, E.C.N.; TRINDADE, R.C.P.; BROGLIO, S.M.F.; DUARTE, A.G.; RODRIGUES, V. de M.; LIMA, H.M.A.; BATISTA, N.S.; SANTOS, J.R. dos. Aspectos biológicos de Aphis craccivora Koch (Hemiptera: Aphididae) em cultivares de feijão-caupi Vigna unguiculata (L.) Walp. Ciência Agrícola, v.12, p.17-20, 2014. DOI: https://doi.org/10.28998/rca.v12i1.1072. 